\title{
SOCIAL MEDIA AND IMPLICATION FOR EDUCATION: CASESTUDY IN FACULTY OF TECHNOLOGY AND SCIENCE UNIVERSITAS BUDDHI DHARMA, TANGERANG, INDONESIA
}

\author{
Harisa Mardiana \\ Faculty Technology and Science \\ Universitas Buddhi Dharma, Tangerang, Indonesia \\ harisa.mardiana@buddhidharma.ac.id \\ soehanadiharisa@gmail.com
}

\begin{abstract}
Nowadays, people have demonstrated the same amount of internet usage, and surprisingly, students have demonstrated more and have consumed a lot of time of using social media site. Not only the college students but also the educators, and they belief about social media sites because in general social media and internet were very helpful; they have found what they needed in education. Facebook for example, it is the resources for education, which are linked to other sources. We observed the implication of social media to the education process and found out about the numerous ways, positive and negative. The result of this paper showed that among the students and educators surveyed no difference usage between college students and educators to assess the social media and internet. The research was created and deployed. We propose that there is an opportunity to leverage social media in college courses to deliver content and to engage students and educators in ways not previously possible.
\end{abstract}

Keywords: social media, Facebook, internet, education.

\section{Introduction}

Recently, we cannot ignore social media in our lives. Almost everytime, we use it to announce something, to tell what we do, to see the schedule that our lecturers have made or etc. In term of teaching and learning, most schools use social media to find resources of learning inwhich technology can play role to increase effective learning process. Although there remains disconnect between educator's ambition for interactive learning through technology and the realities of our practice, the educators mostly use it for their teaching. (Prensky, 2001). Using social media gives the implication to the students, educators and education itself in a learning process. Social media is linked to other sources on internet to help them in their education(Pitler, Hubbell, \& Malennoski, 2007). This gives the learning process run well. The use of social networking in education, coupled with face-to-face engagement, can enable greater inclusiveness for learners, although the role of teachers needs to be well supported to develop successful digital pedagogies (White. Garry, 2012)

On the other side, sometimes some students misuse the internet because they want to connect to other sources such as games, comments from friends which it doesn't connect to the learning process. And some other side, the educators or lectures have difficulty in using internet especially the social media like Facebook. (Jump, 2011) presented that even though 
the classroom itself needs attention to both of them where the contact learning process is created.

Purpose of study was conducted:

1. Is there any positive way or negative way of using social media, Facebook and internet for the education process?.

2. Is there any difference way of using social media, Facebook and internet between students and lecturers?

3. Is there any big opportunity of utilizing social media, Facebook and internet in university program to deliver learning content and engage students and lecturers in ways not previously possible?

4. Is there any implication of social media for education?

\section{Literature Review}

Social media is the platforms that enable the interactive web by engaging users to participate in, comment on and create content as means of communicating with their social graph, other users and the public which have content formats including text, video, photographs, audio, PDF and PowerPoint.(Cohen, 2011). It can be said that social media is the tools, services, and communication facilitating connection between peers with common interests.

Using social media in a learning process begin to rise significantly and likely to imply for education practice and provision especially in term of connecting with their students or with their colleagues, to access news and appear in their walls. (Patel, Social Media management, 2016). Learning that is based around principles of collective exploration, play and innovation rather than individualized instruction (Thomas, 2011). This fact can be used with in a classroom situation to create more value to learning.

One of the social media site is Facebook. Actually, Facebook is a social utility that helps people communicate more efficiently with their friends, family and coworkers. (Zuckerburg, 2005). Now, Facebook is used to connect educators and students that give the schedules, news and everything. In fact, this notion of using social media as a learning tool has carried over to the business world. As a social network site, Facebook appears in public discourse while it is possible that educators have been reluctant to use it as a media for learning and teaching, but without disrupting the flow of work in the classroom, the lecturers and students can ask questions and responses on the lesson and post photos or related sources with hyperlinks. In this way, everyone remains on the same page with few interruptions (Matteson, 2011).

As an incredible learning tool, teacher can utilize Facebook for class project, for enhancing communication and for engaging students in a manner that might not be entirely possible in face to face classroom setting. An excellent way to ensure students are more engaged in the learning experience in the classroom is by strengthening the communication between students and student-to-teacher to keep current information flowing through the class. (Writer, 2009).

By spending so much time working with new technologies, students develop more familiarity with computers and other electronic devices. With the increased focus on technology in education and business, this will help students build skills that will aid them throughout their lives.(Dunn, 2011). 
For the university, using Facebook as a learning tool is cheaper than Moodle. All faculties appreciated the quality and unique type of engagement with students on Facebook, as well as the visual resources that permitted a different type of knowing and learning.(Hocoy, 2013).

But, many students rely on the accessibility of information on social media specifically and the web in general to provide answers. That means a reduced focus on learning and retaining information and also students, who attempt to multi-task, checking social media sites while studying, show reduced academic performance. Their ability to concentrate on the task at hand is significantly reduced by the distractions that are brought about by YouTube, Stumbleupon, Facebook or Twitter(Dunn, 2011). Moreover, students spend more time on social media and less time socializing in person are less able to effectively communicate in person.

One consistent theme in the student feedback is the need for more structure, including a syllabus with clear learning objectives and guidelines for participation and assignments, as well as weekly discussion topics, assignments, or projects. Students were seemingly unaccustomed to the freedom afforded by the absence of a syllabus.(Hocoy, 2013). And the faculty has difficulty to load students' posts and the linked blogs and web pages.(Mali. Alaa.S.M and Syed Hasan, 2013). Furthermore, the benefit of Facebook is to give a familiar atmosphere to students and lecturers and Facebook's design promotes social interchange between participants, thereby increasing collaboration between students working on activities; also the instructors or lecturers can take this opportunity to teach students how to responsibly use Facebook and other social networking sites so it helps their future-not the opposite.(VanDoorn \& Eklund, 2013)

\section{1. Method}

\section{Methodology}

The research study conducted the stages in taking or obtaining the data from the sources, preliminary survey, interviews and questionnaires are shown. Diagram of research is shown in Figure 3.1.

Figure 3.1 Diagram of Research

\begin{tabular}{|cc|}
\hline $\begin{array}{c}\text { Diagram } \\
\text { of } \\
\text { Research }\end{array}$ & $\begin{array}{c}\text { Start } \\
\text { Study Literature } \\
\text { Data Survey } \\
\text { Survey Analysis } \\
\end{array}$ \\
Figure 3.1. & Fonclusion \\
& Finish \\
\hline
\end{tabular}

Figure 3.2 Diagram of Interview

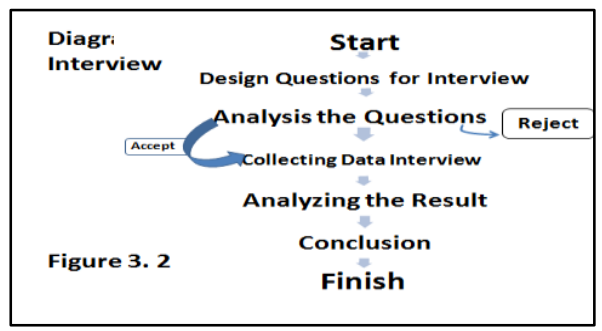

Diagram of questionnaires are shown in Figure 3.3.

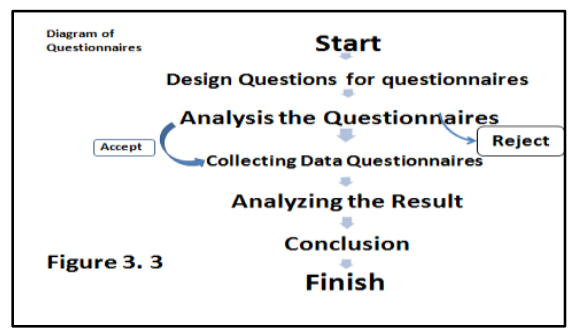


The case itself is in private university, named Universitas Buddhi Dharma, Faculty of Technology and Science, Study Program Information Technology, $4^{\text {th }}$ semester, academic year 2016.

\subsection{Participants}

There are 75 participants with 40 students' semester 4 Information Technology Program Study, and 35 lecturers of Information Technology Program Study from Universitas Buddhi Dharma. The questionnaires are taken in July-August 2016. There are 4 sections of the students, Morning Class and Evening Class, with the age between 18-35 years old and the lecturers' ages are between 25-65 years old among males and females.

\subsection{Materials}

A major portion of the study was the creation and deployment of social media and internet usages and implication to education with questionnaires 14- item questionnaires developed to measure respondent beliefs about social media sites in general. Prior to the study, an extensive exploratory phase was conducted in order to better ascertain that issues of importance to users and nonusers of social media. This is the 14-item social media questionnaires to both students and lecturers. The questionnaires are divided into 3 categories:

1. Positive way of using social media is on questions no. $1,4,6,7,10,11$.

2. Different between students and lecturers of using social media is on questions 2,9 , 14.

3. Opportunity of university using social media is on questions no. 3, 5, 8, 12, 13 .

\subsection{Procedure}

Lickert-scale was used for the items, of which 5 questions are about positive way of using social media, 3 questions are about different usage of social media between students and lecturers, 5 questions about the opportunity of utilizing social media, Facebook and internet in for students and lecturers. The scale was pre-tested with volunteer subjects prior to deployment in this study. The pre-test was used to check for any difficulties in comprehending the items, as well as the overall technicalities of the instrument. The questionnaires were developed and based on the survey instrument from the literatures and feedback from interviewers. Many questionnaires were revised by researchers with experiences in implementing a learning process and social media and Facebook in teaching. We use Likert scale questions from [1] strongly disagree, [2] disagree, [3] agree, [4] strongly agree. A pilot test of the instruments was conducted with 40 students and 35 lecturers who have strongly belief that social media, Facebook and internet help them a lot in teaching and learning process.

\section{Hypothesis}

No substantial problems in working or mechanics were recorded. Students and lecturers have historically existed in both media consumption and technology usage. These difference forming the bases of many of our hypothesized relationships. Based on the literature and data reported, the hypothesis will be significances between students and lecturers with regard to internet and social media usage, as well as beliefs about social media. (Figure 4)

The hypothesis of the research: 
R1. The implication of social media for the education process by having found the positive and no negative way.

R2. There is no difference way of using social media, Facebook and internet between students and lecturers.

R3. There is big opportunity of utilizing social media, Facebook and internet in university program to deliver learning content and engage students and lecturers in ways not previously possible.

R4. There is an implication of social media for education

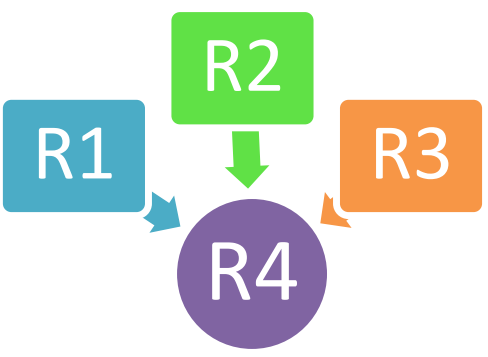

\section{Result}

Figure 5. The demographic profile and descriptive statistics of the respondents $(\mathrm{N}=75)$.

\begin{tabular}{lcc}
\hline \multicolumn{1}{c}{ Measure and Items } & Frequency & Percentage (\%) \\
\hline Category & 40 & \\
Students & 35 & $53.3 \%$ \\
Lecturers & & $46.6 \%$ \\
Class & 20 & \\
Morning Class & 20 & $26.6 \%$ \\
Evening Class & 35 & $26.6 \%$ \\
Lecturers & & $46.6 \%$ \\
Time Usage & 11 & \\
Students (3-5 hours) & 24 & $67.5 \%$ \\
Students (6-8 hours) & 5 & $12.5 \%$ \\
Students (9-12 hours) & 18 & $51.43 \%$ \\
Lecturers (3-5 hours) & 14 & $40 \%$ \\
\hline Lecturers (6-8 hours) & 3 & $8.57 \%$ \\
\hline Lecturers (9-12 hours) & & \\
\hline
\end{tabular}

There are 75 respondents for this research, with 40 students (80\%) age 18-35 years old; which divided by 20 students $(26.6 \%)$ in the morning class, 20 students $(26.6 \%)$ in the evening class and 35 lecturers $(46.6 \%)$ age $25-65$ years old. We conducted a number of indepth interview with various students of Study Program Information Technology, Faculty of Science and Technology and also examine the validity and reliability of research model through 12-week of studying. In this research, the Statistical Package for the Social Sciences version 16 (SPSS v.16.0) was used for statistical analysis.

The first step in the analysis was to assess the reliability of the social media and the questionnaires were presented to improve face and content validity. 
Table 5.1. Descriptive statistics, reliabilities among study variables $(\mathrm{N}=75)$

\begin{tabular}{ccccccc}
\hline Variables & Means & SD & (R1) & (R2) & (R3) & (R4) \\
\hline R1 & 15.63 & 1.964 & $(.749)$ & & & \\
R2 & 12.59 & 2.411 & & $(.699)$ & & \\
R3 & 16.19 & 2.865 & & & $(.814)$ & \\
R4 $^{\text {b }}$ & 41.56 & 4.418 & & & & $(703)$ \\
\hline
\end{tabular}

${ }^{a}$ Reliabilities (Cronbach's $\alpha$ ) are in parentheses.

${ }^{\mathrm{b}}$ Dependent variables: Implication for education

Reliability was examined using Cronbach's $\alpha$ values for each variable. As it is shown in Table 5.1, the values of four variables were strong, which a commonly acceptable level. The reliability of $\mathrm{R} 1=.749 ; \mathrm{R} 2=.699 ; \mathrm{R} 3=.814$ and $\mathrm{R} 4=.703$. From 75 respondents we found that the highest reliability is $\mathrm{R} 3 \alpha=.814$. It is about the opportunity of university to utilize the internet for the learning process. Both students and lecturers agree to have internet as a learning tool and the second one is $\mathrm{R} 1 \alpha=.749$. It is about the implication of social media and has positive way and no negative way. The third is $\mathrm{R} 4 \alpha=.703$. It is about the implication of social media for education. The last one is R2 $\alpha=.699$ it is about liking of using internet.

Table 6.2. Descriptive statistics correlation between variables, $(N=75)$

\begin{tabular}{ccccccc}
\hline Variables & Means & SD & R1 & R2 & R3 & R4 \\
\hline R1 & 18.73 & 2.42 & .910 & & & \\
$\mathbf{R 2}$ & 9.40 & .805 & .113 & -.017 & & \\
$\mathbf{R 3}$ & 16.19 & 2.865 & .642 & -.390 & .869 & \\
$\mathbf{R 4}$ & 41.56 & 4.418 & .899 & -.017 & .869 & .992 \\
\hline **Correlation is significant at the level of .001 level & &
\end{tabular}

This is the correlation of variables from questionnaires that the respondents filled out. The correlation is to analyze correlate between one point to another point.

The second step in the analysis was to assess the correlations between variables, Table 6.2. $\mathrm{R} 4(\mathrm{r}=.992, \mathrm{p}<0.01)$ has the highest correlation to dependent variable. $\mathrm{R} 1(\mathrm{r}=.910, \mathrm{p}, 0.01)$ has the second highest correlation to the dependent variable. Then it is followed by R3 ( $r=.869$, $\mathrm{p}, 0.01)$. $\mathrm{R} 2$ has the lowest correlation between all of them. It is -.017. $\mathrm{R} 2$ is different because the items on the questionnaires have different one. $\mathrm{R} 2$ is about how they like about internet.

Next, Table 6. 3. is shown about analysis of independent sample-test is used to calculated for R1, R2, R3 and R4 by the following variables: by the summed values of the complete social media and implication for education

Table 5.3. Analysis of Independent Sample-Test for R1, R2, R3 and R4

\begin{tabular}{llllllll}
\hline Variable & N (75) & Mean & SD & $t$ & $d f$ & $p$ & $\begin{array}{l}\text { 95\% Confidence } \\
\text { Interval }\end{array}$ \\
\cline { 3 - 5 } & & & & & & Lowest Highest \\
\hline
\end{tabular}




\begin{tabular}{lllllllll}
\hline $\mathbf{R 1}$ & 40 Students & 18.88 & 2.409 & .539 & 73 & .592 & -.820 & 1.427 \\
& 35 lecturers & 18.57 & 2.465 & .538 & 70.696 & .592 & -.822 & 1.429 \\
$\mathbf{R 2}$ & 40 students & 6.28 & 1.219 & -.140 & 73 & .889 & -.599 & .521 \\
& 35 lecturers & 6.31 & 1.207 & -.140 & 71.868 & .889 & -.599 & .520 \\
$\mathbf{R 3}$ & 40 students & 16.15 & 2.851 & -.118 & 73 & .907 & -1.409 & 1.252 \\
& 35 lectures & 16.23 & 2.921 & -.118 & 71.186 & .907 & -1.412 & 1.255 \\
$\mathbf{R} 4$ & 40 Students & 41.30 & 4.195 & .014 & 73 & .989 & -.1 .972 & 2.001 \\
& 35 lecturers & 41.29 & 4.430 & .014 & 70.470 & .989 & -1.981 & 2.009 \\
\hline
\end{tabular}

In R1 is about positive way of using social media and indicated that there was no statistically significant difference between students and lectures, because $p$ (students) $0.592 \geq 0.05$ and $p$ (lecturer) $.592 \geq 0.05$, we have found that there is no negative way and have found positive way of using social media, Facebook and internet for education. R2 is about difference way of using social media, Facebook and internet between students and lecturers. With $p$ (students) $.889 \geq 0.05$ and $p$ (lecturers) $.889 \geq 0.05$, it is found that there is no difference way of using social media, Facebook and internet for education. R3 is about the opportunity of university using social media, Facebook and internet, we have found out that $p$ (students) $.907 \geq 0.05$, and $p$ (lecturers) $.907 \geq 0.05$, it is indicated that there is an opportunity for university to engage students and lecturers. R4 is about implication social media for education, $p$ (students) $.989 \geq 0.05$ and $p$ (lecturers) $.989 \geq 0.05$, and it is indicated that there is an implication of social media, Facebook and internet to engage students and lecturers.

And then the research study is assessed for the time usage of social media and internet. It is shown on table 5. 4.

Table 5. 4. Time Usage of Social Media and Internet between students and lecturers

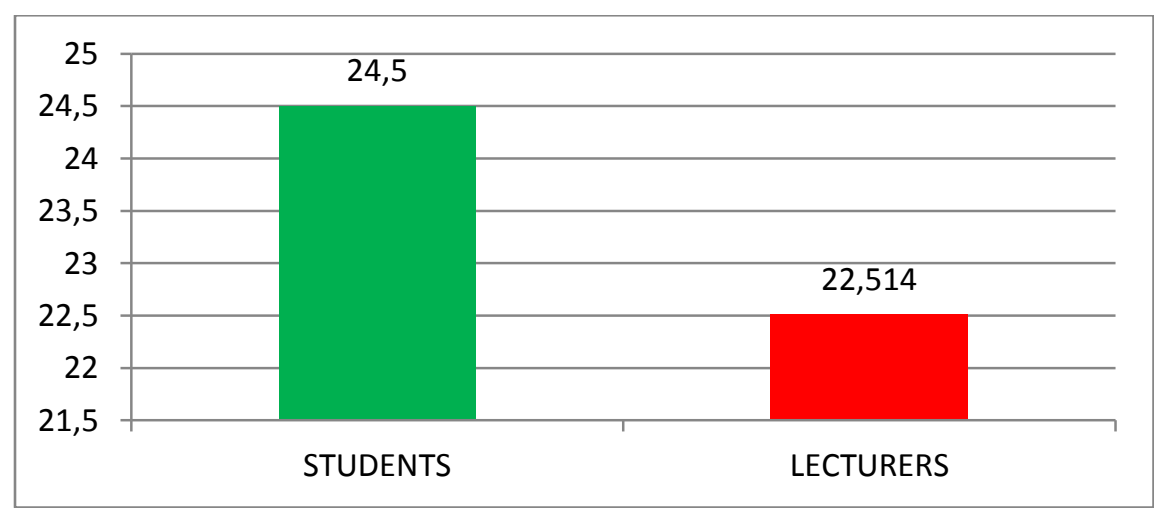

For time usage of social media and internet, it is indicated that the students have spent more time (24.5 hours per month) than lecturers (22.514 hours per month). It is 1.986 hours per 
week. Even though lecturers has a slightly lower than students, lecturers spent more time to upload the material on the internet, social media and Facebook. (Zakaria, 2016). And on the other hand, students are sorting the learning subjects which it is uploaded on the internet, the students begin to look up the subject. Actually the students come to the class, they have already opened the social media, Facebook or internet, but they don't connect it to the learning process. They look at on their own personal social media, Facebook or internet(Kienata, 2016).

\section{Discussion}

It is indicated that a major educational implication of social media is the apparently changing nature of learners' relationships with information and knowledge. (Selwyn, 2011). Social media is gaining its momentum at an unimaginable speed. It indicates that we, as social beings, need constant connection with each other and with the outside world. (Liu, 2010). Regarding the process of adopting social media in the classroom, previous studies indicate that students perceive the use of social media for learning purposes in a positive manner (Kumar, 2009). Based on three scholars we conclude that social media has found its way quickly into the commercial world, at the same time educators are seeking possibilities of leveraging social media tools in educational arena. Social media tools provide learners with new opportunities to become independent in study and research.

Figure 6. Social media in Learning Process

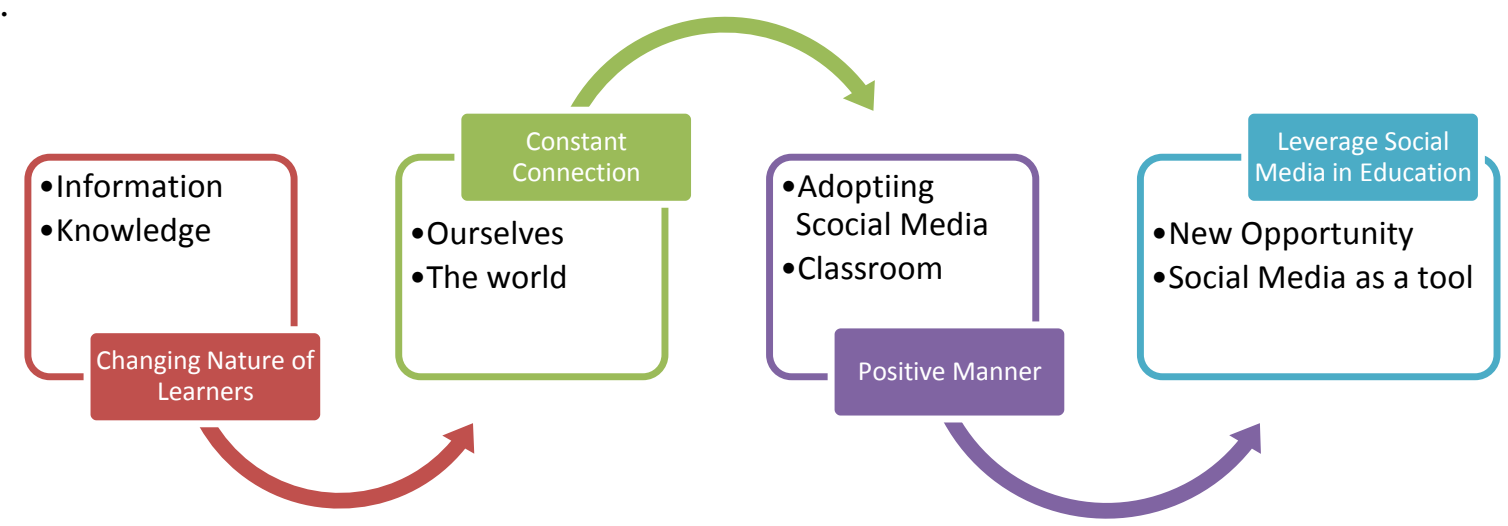

Even though social media support forms of knowledge consumption and knowledge construction, the students may ask the lecturers on Facebook the principles of the subject and the lecturers gives the instruction and explanation directly on Facebook. Regarding to the relationship between using social media with the grades of college students, concurrent with past studies that online communication is linked to time spent in offline relationships. (Jacobsen \& Forste, May 2011). This takes time to answer the question in offline relationships; students may lose interest on the learning process. With this kind of technology, there is an opportunity to exchange the ideas, share knowledge and given to other person information, links and else. Within a few minutes after asking the ideas or knowledge, we enjoy the information. This is very useful for lecturers in the digital age, horizon of the world seemed to be in touch of our fingers. (Wicaksana \& Puspitawati, 2015).

Regarding to the relationships between students concurrent with the past studies that find that online communication is linked to time spent in offline relationships. "Our findings indicate that social media or social networking site use cellular-phone communication facilitates 
offline social interaction, rather than replace it. (Jacobsen \& Forste, May 2011). With the social media, Facebook and internet students commonly commented that connect should be invaluable for making friends and supporting each other, especially within the first few weeks after arriving at the University.(Oradini \& Saunders, 2010). We can say that R2 (no difference of using social media, Facebook and internet between students and lecturer) is answered.

With all of the students and lecturers use a lot of social media site, especially Facebook, it would not be a technology impossibility to utilize the popular social media as a means of content delivery by engagement between students and lecturers. This can be accomplished by the course lecturers creating and maintaining a Fan Page, at no cost to anyone involved and completely apart from the limitations of course management systems such as Blackboard, Angel and WebCT. (Gerlich, Browning, \& Westmermann, 2010).

Based on the result from Independent t-test about questionnaires, we have found out that there is a positive way of using social media, Facebook and internet for education. Both students and lecturers have increased effective in learning process. The use of social networking in education, with good engagement, can enable greater inclusiveness for learners, although the role of teachers needs to be well supported to develop successful digital pedagogies.(White. Garry, 2012). Students and lecturers have used the social media, Facebook and internet in learning process. In the class, lecturers have let students use the social media only for the context of learning process and students have obeyed the rules that the lecturers have given. (Lam, 2012). Students and lecturers are belief of social media, Facebook and internet to interact with others and gain their knowledge.

With social media, Facebook or internet as a catalyst for changing communication practices. Also they believe that social networking is a learning tool to engage a learning process inside or outside the class. (Pimmer, Linxen, \& Gröhbie, 2012). It is indicated that it is likely to be a result of chance about the way of using social media, Facebook and internet. It is also supported by the hours that they have spent, students spent 24.5 hours per-month and lecturers spent 22.514 hours per-month. Students spent more or 1.986 hour per-month than lecturers. This gives good opportunity for learning and teaching process. (S.M., Sariah, \& Hassan, 2013). Social media are a tool to be leverage not avoided. Therefore, it is possible for campus to utilize all of the equipment, tools and technology to engage students and lecturers and have potentially a valuable resource for supporting student communication and collaboration with lecturers. (Jump, 2011).Because with the time changing and with the advance technology and the innovation of learning and teaching process, it is possible for campus to have and install equipment and tools for learning to work well.

Learning not only in the classroom, but also outside the classroom, so by using social media, Facebook and the internet, learning can be proceed smoothly .For the future research, the design of learning and teaching systems that implement the use of social media, especially in regular instruction model can help learners achieve their learning objectives. Therefore, the lecturers and campus staff should be encouraged to use social media or internet in their regular instruction and regular work as this is an effective tool for our learning right now, the $21^{\text {st }}$ century of learning.

\section{Conclusion}


Social media, Facebook and internet are relevant field of education technology and this is still has a long period of evolution. For the students, it is a challenge to learn via social media, Facebook or internet, as the students should be very serious to adopt it. There is no way for students not learning seriously, if it happens, the students will go beyond the context of learning, since the learning process goes forward. With there is no negative way of using social media, Facebook and internet, so, they can be viable for the use in learning process. It is important to work in different kind of educational designs that enhance the use of social media, so the campus itself must follow the development of technology, advances technology and learning innovation in $21^{\text {st }}$ century. The implication of social media, Facebook and internet in students and lecturers perceptions are very important for future learning. At the same time, both students and lecturers are able to receive the new pedagogical potentials in learning English if they are given the opportunity to incorporate with assignments, feedback from two ways communication and collaborative work. (S.M., Sariah, \& Hassan, 2013).

\section{Reference:}

Cohen, H. (2011, May 9). Social Media Definition. Retrieved from Heidi Cohen: http://heidicohen.com/social-media-definition/

Dunn, J. (2011, July 11). The 10 Best and Worst Ways Social Media Impacts Education. Retrieved from Edudemic Connecting Education and Technology: http://www.edudemic.com/social-media-education/

Gerlich, N. ,., Browning, L., \& Westmermann, L. (2010). The Social Media Affinity Scale: Implication for education. Contemporary Issues In Education Research, 38.

Hocoy, D. (2013, December 6). Facebook as Learning Management System: The Good, the $\mathrm{Bad}$, and the Unexpected. Retrieved from Educausereview: http://er.educause.edu/articles/2013/12/facebook-as-learning-management-systemthe-good-the-bad-and-the-unexpected

Jacobsen, W., \& Forste, R. (May 2011). The Wired Generation: Academic and Social Outcomes of Electronic Media Use Among University Students. Cyberpsychology, Behavior, and Social Networking - 14(5), 275-280.

Jump, L. (2011). The experiences of University Lecturers when enhancing their teaching through the use of digital technology: a systematic review. Higher Education Academy School of Health and Social Care, 8.

Kienata, M. (2016, August 15). Spending Time on Internet and Social Media. (H. Mardiana, Interviewer)

Kumar, S. (2009). Undergraduate perceptions of the usefulness of Web 2.0 in higher education: Survey Development. CiteSeer, 308-314. 
Lam, L. (2012). An Innovative Research on the usage of Facebook in the Higher Education context of Hong Kong. The Electronic Journal of e-Learning Volume 10 Issue 4, 377386.

Lee, M. \&. (2008). Harnessing the Affordance of Web.2.0 and Social software Tools: Can we finally make "Student Centered" Learning A Reality? Presented at the World Conference on Multimedia, Hypermedia and Telecommunications., 6.

Liu, Y. (2010). Social Media Tools as a Learning Resource. Journal of Educational Technology Development and Exchange, 109.

Mali. Alaa.S.M and Syed Hasan, S. S. (2013). STUDENTS' ACCEPTANCE USING FACEBOOK AS A LEARNING TOOL: A CASE STUDY. International Journal of Asian Social Science, 2020.

Matteson, A. (2011, February 5). Do You Tumble? Tumblr Could Change the Way You Blog. Retrieved from Keeping Current: https://tumblrforlibraries.wikispaces.com/file/view/Do+You+Tumble

Oradini, F., \& Saunders, G. (2010). The Use of Social Networking By Students and Staff In Higher Education. Online Learning Development University of Westminster, UK, 4.

Patel, N. (2011, June 11). A Day In The Life. Los Angeles, California, USA.

Patel, N. (2016, February 16). Social Media management. Los Angeles, California, USA.

Pimmer, C., Linxen, S., \& Gröhbie, U. (2012, October 11). Willey. Retrieved July 27, 2016, from British Journal of Educational Technology: http://onlinelibrary.wiley.com/doi/10.1111/j.1467-8535.2012.01351.x/abstract

Pitler, H., Hubbell, E. R., \& Malennoski, K. (2007). Using Technology With Classroom Instruction That Works. Alexandria, Virginia: Association for Supervision and Curriculum Development.

Prensky, M. (2001). Digital Natives, Digital Immigrants . Marc Prensky, 2.

S.M., M. A., Sariah, S., \& Hassan, S. (2013). Students' Acceptance Using Facebook As A Learning Tool: A Case Study. International Journal of Asian Social Science, 2024.

Selwyn, N. (2011). Social Media in Higher Education. Sample Essay - Selwyn, 3.

Thomas, D. a. (2011). A New Culture of learning. Charleston, SC: Createspace.

VanDoorn, G., \& Eklund, A. A. (2013). Face to Facebook: Social media and the learning potential of Symmetrical and Sychronous communication. Journal of University Teaching \& Learning Practice Volume 10 Issue 1 Article 6, 9. Retrieved September 4, 2016, from Online College.org: http://www.onlinecollege.org 
White, G. K. (2012). Digital social networking : implications for education" Professional Educator. Australian Council for Educational Research, Vol. 11 Iss. 5 , 1.

White. Garry, K. (2012). Digital social networking : implications for education" Professional Educator. Australian Council for Educational Research, 1.

Wicaksana, I. W., \& Puspitawati, I. (2015, December 4). Dampak Media sosial Terhadap Dunia Pendidikan. Retrieved from Kantor Berita Kemanusiaaan: http://kemanusiaan.id/2015/12/04/peran-media-sosial-untuk-pendidikan/

Writer, S. (2009, October 20). 100 Ways You Should Be Using Facebook in Your Classroom. Retrieved from Online College.org: http://www.onlinecollege.org/2009/10/20/100ways-you-should-be-using-facebook-in-your-classroom/

Zakaria. (2016, August 10). Spending Time on Internet and Social Media. (H. Mardiana, Interviewer)

Zuckerburg, M. (2005). Facebook Mission and Vision. Melo Park, California: Facebook. 